\title{
The Effect of Audit Quality, Managerial Ownership, and Audit Committee on Integrity of Financial Statements (Empirical Study of Property and Real Estate Companies at Idx 2014-2018)
}

\author{
Nur Isna Inayati ${ }^{1}$, Siti Nur Azizah ${ }^{2}$, Shulasi Nur Haalisa ${ }^{3}$, Dwita Ayu Rahmadanti ${ }^{4}$ \\ 1,2,3,4Faculty of Economic and Business, Universitas Muhammadiyah Purwokerto \\ nurisna.inayati@ump.ac.id ${ }^{1}$, sitinurazizah@ump.ac.id²
}

\begin{abstract}
This study aims to examine the effect of audit quality, managerial ownership, and audit committee on the integrity of financial statements. The population used in this study are property and real estate companies listed on the Indonesia Stock Exchange (IDX) for the 2014-2018 period. Sampling in this study used a purposive sampling method and obtained 95 samples from 19 property and real estate companies from 2014-2018. The data analysis technique used is the logistic regression analysis method. The results of this study indicate that managerial ownership has a positive effect on the integrity of financial statements. Whereas the audit quality and audit committee have no positive effect on the integrity of financial statements.
\end{abstract}

Keywords: Audit quality, managerial ownership, audit committee, financial statement integrity

\section{Introduction}

Based on the 2011 PSAK the qualitative characteristics that financial statements must have to be used in the decision-making process, companies must realize the integrity of financial statements. But the reality of realizing the integrity of financial statements is difficult. Proven so many cases of manipulation of financial statements. Many companies present information in financial statements in the absence of integrity, where the information submitted is incorrect and unfair for some users of financial statements [1].

According to [2], integrity is an honest and impartial moral principle. High integrity will make people see the facts as they are. High integrity needs to be reflected in financial statements because it illustrates the value of the company. this can be a positive value for the viewpoint of investors, creditors, or other parties interested in the company. According to [3], integrity is honest and what it is Financial statements that have integrity are financial statements that show the actual condition of a company, without being hidden and covered up. Integrity financial statements will have information that is certainly honest and naturally free from errors and biases in presenting what is intended to be stated. 
The phenomenon of financial scandal cases in the financial statements that occur proves that there is still a lack of honesty in producing financial statements with integrity and presenting information in financial statements with actual conditions. The company made the wrong decision so that there was fraud in preparing the financial statements. The company's management tends to be scandalous due to various factors to keep the company in good condition so as not to make shareholders worry[4] (Aditya 2018).

Several factors can affect the integrity of a financial statement, the first is the quality of the audit. The quality of the audit is the state in which auditors can find and report violations. The auditor's ability to find errors depends on the auditor's technical competence, then when the auditor has to pour into the report depending on the independence of that auditor can be seen how important the quality of audits is. With high audit quality, the financial statements can be relied upon as a reference for decision making.[3].

The second factor is managerial ownership. Managerial ownership is joint management ownership of the company as measured by the percentage of shares held [26]. According to[5]if management participates in owning shares of the company, then the manager must be able to act in the interests of the owner where management will act more cautiously because there is a sense of mutual ownership. So that it is expected to reduce manipulation in reporting financial information and will improve the integrity of the financial statements themselves.

Furthermore, the factors that influence the integrity of the financial statements are the audit committee. According [6], audit committee is a committee created by the board of directors that has the task of conducting external audits and independent oversight of financial statements. The audit committee has the responsibility in overseeing the auditing of financial statements, ensuring the fulfillment of financial standards and policies, checking the suitability of financial statements with standards and policies, and ensuring the financial statements made are consistent with other information known by members of the audit committee. If the number of audit committees is increased, then the pressure of management to produce financial statements with integrity will be greater.

Based on the background that has been described, the formulation of the problems in this study are: (1) Does audit quality have a positive effect on the integrity of financial statements; (2) Does managerial ownership have a positive effect on the integrity of financial statements; (3) Does the audit committee have a positive effect on the integrity of the financial statements

In accordance with the research problem above, the objectives of this study are: (1) To find empirical evidence of the influence of audit quality on the integrity of financial statements; (2) To find empirical evidence of the influence of managerial ownership on the integrity of financial statements. (3) To find empirical evidence of the influence of the audit committee on the integrity of the financial statements.

\section{Theory Basis}




\subsection{Agency Theory}

The Agency theory explains the relationship between the two parties, namely the owner and management. Principal-agent relations occur when the actions taken by someone have an impact on others. According to[7] defines that the theory of the institution is a situation in which there is a contractual relationship with one or more persons (owners) arranging for another person to perform services on behalf of the owner and authorizing the agent to make the best decision for the principal if needed. There are two types of agency relationships, namely between managers and shareholders and between managers and bondholders. The separation between company control and ownership is one of the factors that trigger a conflict of interest, better known as agency conflict. Agency conflict that arises between various parties who have many interests can make it difficult and hinder the company in achieving positive performance to produce useful value for the company itself and also for shareholders. In addition, the existence of an imbalance in the mastery of information can trigger the emergence of a condition called information asymmetry (information asymmetry).

The agency's theory is closely related to good corporate governance. In this study, managerial ownership and audit committees are important aspects of good corporate governance. The existence of corporate governance can reduce costs so as to improve the quality of financial statements.

\subsection{The Integrity of Financial Statements}

The integrity pact is the commitment of management or leadership in implementing good corporate governance (GCG) in the company. The integrity pact contains commitments or promises to carry out all duties, obligations, and responsibilities in accordance with applicable regulations. In this case, management has the duty and responsibility to always act honestly, can be trusted, avoid conflict of interest, anti-KKN (corruption, collusion, and nepotism), and antibribery. This integrity pact was introduced by Transparency International around the mid-1990s [8]. According [9], [22], the calculation of the integrity of financial statements is proxied by conservatism, namely:

Information:

$$
\text { CONACCit }=\text { NIit }- \text { CFOit }
$$

CONACCit $=$ Conservatism index of the company $\mathrm{i}$ in $\mathrm{t}$.

NIit $=$ Net income before extraordinary items is added to depreciation and amortization.

CFOit $\quad=$ Cash flow from operating activities

\subsection{Audit Quality}

Audit quality is a state where auditors can find and report violations that exist in the accounting system. The auditor's ability to find incorrect statements is influenced by the auditor's technical 
ability. Meanwhile, the mis-reporting of statements depends on the independence of the auditor. From this can be seen the importance of audit quality. Reliable financial statements as the basis of decision making are the result of high audit quality[3].

\subsection{Managerial Ownership}

Managerial ownership is a shareholding by two parties, namely the manager and director of the company. Shareholders that authorized to manage the company both as creditors and as the board of commissioners are referred to as managerial [10][25].Measuring instruments used in measuring managerial ownership are: Managerial Ownership (MOWN) is measured by the Managerial Ownership ratio. Managerial Ownership is ownership of shares by company management as measured by the percentage of shares owned by management [11].

$$
\text { Managerial ownership }=\frac{\text { number of shares owned by management }}{\text { number of shares outstanding }} \times 100 \%
$$

\subsection{Audit Committee}

The audit committee is the result of the establishment by the board of directors in charge of conducting external audits and independent oversight of financial reporting. In financial reporting, the audit committee has a role and responsibility to oversee audits of financial statements and ensure the fulfillment of financial standards and policies, re-examine the financial statements if they are in accordance with these standards and policies and whether they are consistent with other information known by committee members. audit, and assess the quality of service [23]. According to[3], the audit committee is measured using the number of audit committee members in the company. Audit committees are measured in units of people.

\subsection{Effect of Audit Quality on the Integrity of Financial Statements}

The quality of a public accountant is a measure used to determine the size of a public accounting firm. The size of the Public Accounting Firm can be said to be large if the KAP is affiliated with Big 4, has branches and its clients are large companies and have a professional staff of more than 25 people. Whereas the size of a Public Accounting Firm is said to be small if it is not affiliated with Big 4, does not have a branch office and its clients are small companies and the number of professionals is less than 25 people. A large KAP is more independent than a small KAP [21].

The reason is that when a large KAP loses one client, it does not significantly affect its income. However, if a small KAP loses one client it is very meaningful because the client is few [3]. Based on the description above, the first hypothesis tested in this study is H1: Audit quality has a positive effect on the integrity of financial statements.

\subsection{The Effect of Managerial Ownership on the Integrity of Financial Statements}


According to[12], [20], managerial ownership is able to be a mechanism in overcoming agency conflicts from managers by aligning the interests of managers and shareholders. According to[13], managerial ownership has the authority to limit the deviant behavior of the company's management . Managerial ownership is one mechanism that can be applied to improving the integrity of financial statements. Based on the description above, the second hypothesis in this study is formulated as follows $\mathrm{H} 2$ : Managerial ownership has a positive effect on the integrity of financial statements.

\subsection{The influence of the Audit Committee on the Integrity of Financial Statements}

According to the National Committee on Good Corporate Governance[14], the Audit Committee which is the result of the board of directors has the task of conducting external audits and independent oversight of financial reporting. According to [24], to improve the credibility of financial statements, the audit committee assists the board of commissioners to monitor the financial reporting process by management. Based on the above description, the third hypothesis tested in this study is formulated as follows H3: The audit committee has a positive effect on the integrity of the financial statements.

\section{Method}

\subsection{Data Collection Method}

Secondary data in this study is the annual financial statements of property and real estate companies listed on the Indonesia Stock Exchange in the period 2014-2018. The supporting data of this research is in the form of audit quality data, managerial ownership, audit committee. Data collection is done by documentation method. Literary studies are obtained from previous research and supported by other literature. The company's financial statements are obtained on the official website of the Indonesia Stock Exchange (IDX), www.idx.co.id.

\subsection{Operational Definition and Variable Measurement}

\section{a) The Integrity of Financial Statements}

The integrity of financial statements is the financial statements that are presented in accordance with reality. Financial statements are said to have integrity if financial statements can be presented by showing true and honest information [15].

\section{b) Audit Quality}

According to [16] audit quality is a state where auditors can find and report violations that exist in the accounting system. The auditor's ability to find incorrect statements is influenced by 
the auditor's technical ability. Meanwhile, the misreporting of statements depends on the independence of the auditor. From this can be seen the importance of audit quality. Reliable financial statements as the basis of decision making are the result of high audit quality.

\section{c) Managerial ownership}

According to [17] Managerial Ownership is a shareholding by two parties, namely the manager and director of the company. Shareholders that authorized to manage the company both as creditors and as the board of commissioners are referred to as managerial. Managerial Ownership (MOWN) is measured by the Managerial Ownership ratio. Managerial Ownership is ownership of shares by company management as measured by the percentage of shares owned by management [11].

\section{d) Audit Committee}

According to [18], The audit committee is set up by the company to be a liaison between directors and external auditors, internal auditors, and independent members, with the task of providing auditor oversight to ensure management takes appropriate corrective action and adheres to laws and regulations.

\subsection{Data Analysis Methods}

Data analysis in this study was carried out using SPSS (Statistical Package for Social Science). There are several data analysis methods used in this study, namely:

\section{a) Descriptive statistics}

Descriptive statistics provide a description or description of data that is seen from the average value (mean), the standard deviation value, the maximum value, and the minimum value [19].

\section{b) Overall Model Test (Overall Model Fit)}

In this study, assessing hypothetical models that match or not with data can be used to assess the overall model. Testing is done by comparing the possible log value -2 at the beginning (block number $=0$ ) with the possible $\log$ value -2 at the end (block number $=1$ ). The suitability of the hypothesis model with the data can be seen from the reduction in the value between the initial 2LL (initial -2LL function) and the -2LL value in the next step.

\section{c) Feasibility Test Regression Model}


Hosmer and Lemeshow's Goodness of Fit Test. Hosmer and Lemeshow's Goodness of Fit Test is used to assess the feasibility of regression models. If there is no difference between the data so that the data model is said to match (null hypothesis) [19].

\section{d) Determination Coefficient Testing (Nagelkerke's R Square)}

The coefficient of determination (R2) is a test to measure how far the ability of the independent variable in explaining the dependent variable [19]. R2 values range from 0 (zero) to 1 (one).

\section{e) Parameter Estimation and Interpretation}

Parameter estimation can be seen through regression coefficients showing regression. Regression coefficients address the relationship between one variable with another variable. Hypothesis testing is done by comparing the value of profitability (sig).

\section{f) Logistic Regression Test}

The hypothesis test in this study used multivariate analysis in the form of logistical regression used to test the hypothesis. Logistic regression has independent variables in the form of a combination of one more nonmetric metric. So technically, logistics regression analysis does not require a classic assumption test because normal multivariate distribution assumptions cannot be met. After all, independent variables are a mixture of continuous variables (metrics) and categorical (nonmetric) [19]. The logistics regression model used is as follows:

$$
\mathrm{ILK}=\beta+\beta 1 \mathrm{KA}+\beta 2 \mathrm{KM}+\beta 3 \mathrm{KoA}+\varepsilon
$$

\section{Results and Discussion}

\subsection{Population and Samples}

This study used a population of property and real estate companies listed on the Indonesia Stock Exchange (IDX) in 2014-2018. While the secondary data is property and real estate companies listed on the Indonesia Stock Exchange, complete with financial reports and audited reports for the 2014-2018 period, and the company has a year-end period for December 31. Data collection is carried out through www.idx.co.id. In this study, researchers used a purposive sampling method with the aim of obtaining representative samples in accordance with predetermined criteria. 
Table 1. Description of Sampling

\begin{tabular}{clc}
\hline No & \multicolumn{1}{c}{ Research Sample Criteria } & Number of Companies \\
\hline 1 & $\begin{array}{l}\text { Property and real estate companies listed on the } \\
\text { Indonesia Stock Exchange sample 2014-2018 }\end{array}$ & 61 \\
2 & $\begin{array}{l}\text { Companies that do not provide } \\
\text { data needed in research }\end{array}$ & 42 \\
3 & Companies used as samples & 19 \\
4 & $\begin{array}{l}\text { Total sample data used during the 5years study period } \\
\text { (19company x 5 years) }\end{array}$ & 95 \\
\hline
\end{tabular}

\subsection{Data Analysis Results}

\section{a) Descriptive Statistical Analysis}

As explained earlier, the number of data that was initially processed was 95 sample data from 19 companies. The results of the descriptive statistical analysis are seen in the following table.

Table 2. Descriptive Statistical Analysis Test Results

\begin{tabular}{cccccc}
\hline & $\mathrm{N}$ & Minimum & Maximum & Mean & Std.Deviation \\
\hline $\mathrm{KM}$ & 95 & 0 & 32 & 3,10 & 7,843 \\
KoA & 95 & 2 & 5 & 3,12 & 0,581 \\
Valid N & 95 & & & & \\
(listwise) & & & & & \\
\hline
\end{tabular}

Source: Proposed data, 2019

In table 3. shows the average shares owned by management amounted to 33.10 with a standard deviation of 7.843, the minimum value is 0 and the maximum value is 32 . In table 2 . shows the average value of the audit committee sampled in this study is 3.12 with a standard deviation of 0.581 , a minimum value of 2 , a maximum value of 5 .

Table 3. Frequency of Integrity Test Results of Financial Statements

\begin{tabular}{cccccc}
\hline & & Frequency & Percent & Valid Percent & Cumulative Percent \\
\hline \multirow{3}{*}{ Valid } & No Integrity & 87 & 91,6 & 91,6 & 91,6 \\
& Have integrity & 8 & 8,4 & 8,4 & 100 \\
& Total & 95 & 100 & 100 & \\
\hline
\end{tabular}

Source: Proposed data, 2019

The value of financial statement integrity in this study uses a dummy variable with a range of 1 (it can be interpreted that the company has produced financial statements with integrity) and the value of 0 (means the company cannot produce financial statements with integrity), in table 4. 
shows the number of research samples 95 , of The 95 samples categorized 1 were 8 or $8.4 \%$ and those categorized 0 were 87 or $91.6 \%$.

Table 4. Frequency of Audit Quality Test Results

\begin{tabular}{cccccc}
\hline & & Frequency & Percent & Valid Percent & Cumulative Percent \\
\hline \multirow{3}{*}{ Valid } & KAP Non big Four & 63 & 66,3 & 66,3 & 66,3 \\
& KAP Big Four & 32 & 33,7 & 33,7 & 100 \\
& Total & 95 & 100 & 100 & \\
\hline
\end{tabular}

Source: Proposed data, 2019

Audit quality is divided into 2, namely auditors coming from KAP big four and Auditors who are not from KAP big four. This variable is measured using a dummy, where the auditor from the big four KAP is coded 1, while the auditor who is not from the big four KAP is coded 0 . In table 4.5 above shows the number of research samples as many as 95 . Of the 95 samples categorized as 1 as many as 32 or $33.7 \%$, and the rest categorized as 0 as 63 or $66.3 \%$.

\section{b) Logistic Regression Test}

Logistics regression analysis is used to determine the probability of a dependent variable being predicted with an independent variable. This analysis is done because the integrity of financial statements as dependent variables is quantitative data that uses dummy variables, and independent variables are a mixture of continuous and categorical variables [19].

\section{c) Feasibility Test of Regression Model}

Table 5. Hosmer and Lemeshow Test Goodness of Fit Test Results

\begin{tabular}{clll}
\hline Step & Chi-Square & Df & Sig \\
\hline 1 & 13,325 & 7 & 0,065 \\
\hline
\end{tabular}

Source: Proposed data, 2019

In table 5.5 shows the value of statistics Hosmer and Lemeshow Goodness of Fit Test of 13.325 with a significance probability of 0.065 whose value is above 0.05 . This it can be concluded that the model can be accepted, ie the model is able to predict the variables in this study, so that the model can be used for subsequent analysis.

\section{d) Assessing the Overall Model (Over All Model)}

Table 6. Overall Fit Iteration History Model Test Results a, b, c

-2 Log likelihood Coefficients




\begin{tabular}{llll}
\multicolumn{2}{c}{ Iteration } & & Constant \\
\hline \multirow{2}{*}{ Step 0 } & 1 & 59,588 & $-1,663$ \\
& 2 & 55,100 & $-2,224$ \\
& 3 & 54,898 & $-2,376$ \\
& 4 & 54,898 & $-2,386$ \\
& 5 & 54,898 & $-2,386$ \\
\hline
\end{tabular}

Source: Proposed data, 2019

Table 7. Overall Model Fit 2 Iteration History Test Results a, b, c, d

\begin{tabular}{ccccccc}
\hline \multirow{2}{*}{ Iteration } & \multirow{2}{*}{ S Log likelihood } & \multicolumn{4}{c}{ Coefficients } \\
\cline { 3 - 6 } & & & Constant & X1 & X2 & X3 \\
\hline Step 0 & 1 & 56,590 & $-0,852$ & $-0,472$ & 0,027 & $-0,236$ \\
& 2 & 49,151 & $-0,321$ & $-1,155$ & 0,054 & $-0,571$ \\
& 3 & 47,548 & 0,439 & $-1,926$ & 0,076 & $-0,882$ \\
& 4 & 47,339 & 0,715 & $-2,385$ & 0,087 & $-0,996$ \\
& 5 & 47,334 & 0,751 & $-2,482$ & 0,089 & $-1,012$ \\
& 6 & 47,334 & 0,752 & $-2,485$ & 0,089 & $-1,012$ \\
& 4 & 47,334 & 0,742 & $-2,485$ & 0,089 & $-1,012$ \\
\hline
\end{tabular}

Source: Proposed data, 2019

Testing is done by comparing the value between -2 Log Likelihood (-2LL) at the beginning (Block Number $=0$ ) with the value of $-2 \log$ Likelihood $(-2 L L)$ at the end (Block Number $=1$ ). If there is a decrease, it shows a good regression model or a model that is hypothesized fit with the data. Table 6. and table 7. show the overall value of the overall model fit value of the initial -2LL (Block 0) is 54.889 and the final -2LL value (Block 1) is 47.333. This value has decreased, meaning that shows a good regression model or in other words the model is hypothesized fit with the data.

\section{e) Nagelkerke RSquare Value}

Table 8. Nagelkerke R Square Test Results

\begin{tabular}{cccc}
\hline Step & -2 Log likelihood & Cox \& Snell R Square & Nagelkerke R Square \\
\hline 1 & $47,334^{\mathrm{a}}$ & 0,077 & 0,174 \\
\hline
\end{tabular}


Table 5.8 shows the results of the output spss Cox and Snell R Square values of 0.077 and Nagelkerke R Square values of 0.174 which means that the variability of the dependent variable can be explained by the variability of the independent variables by $17.4 \%$, while the remaining $82.6 \%$ of the dependent variable variability is explained by other variables not examined in this study.

\section{f) Parameter Estimation and its Interpretation}

Parameter estimation can be seen through the regression coefficient, where the results can be seen in the following table:

Table 9. Regression Coefficient Testing Results

\begin{tabular}{|c|c|c|c|c|c|c|c|}
\hline & B & $\begin{array}{l}\text { S.E } \\
\end{array}$ & Wald & $\mathrm{Df}$ & Sig. & $\operatorname{Exp}(\mathrm{B})$ \\
\hline \multirow[t]{4}{*}{ Step $1^{\mathrm{a}}$} & $\mathrm{X} 1$ & $-2,485$ & 1,463 & 2,888 & 1 & 0,089 & 0,083 \\
\hline & $\mathrm{X} 2$ & 0,089 & 0,047 & 3,573 & 1 & 0,059 & 1,093 \\
\hline & $\mathrm{X} 3$ & $-1,012$ & 0,833 & 1,478 & 1 & 0,224 & 0,363 \\
\hline & Constant & 0,752 & 2,466 & 0,093 & 1 & 0,760 & 2,122 \\
\hline
\end{tabular}

Source: Proposed data, 2019

From the logistic regression equation test, the logistic regression model is obtained as follows:

$$
\mathrm{ILK}=0,752-2,485 \mathrm{KA}+0,089 \mathrm{KM}-1,012 \mathrm{KoA}+\varepsilon
$$

\section{Conclusions and Limitations of the Study}

\subsection{Conclusions}

Based on the analysis that has been done, the following conclusions can be drawn:

1. Audit quality has a positive effect on the integrity of financial statements accepted, this is evidenced by a significance value of 0.089 and a regression coefficient of -2.485 .

2. Managerial ownership has a positive effect on the integrity of financial statements accepted This is evidenced by the significance value of 0.059 and the regression coefficient value of 0.089 .

3. The audit committee has a positive effect on the integrity of the financial statements rejected. This is evidenced by a significance value of 0.224 and a regression coefficient of 1012.

\subsection{Research Limitations}


a. This research only uses sample objects of property and real estate companies.

b. The observation period is only 5 years 2013-2018.

c. The variables tested in this study were only 3 variables, namely audit quality, managerial ownership and audit committee on the integrity of financial statements. So the influence variables that arise outside the independent variables used, can not be proven scientifically.

\section{References}

[1] Nurjannah, L., \&Pratomo, D. (2014). PengaruhKomite Audit, KomisarisIndependen Dan Kualitas Audit TerhadapIntegritasLaporanKeuangan. E-Proceeding Of Management, 1(3), 99

[2] Adriansano, A. C., \& Nuryantoro. (2015). Pengaruh Independensi Auditor Dan Kualitas Audit Terhadap Integritas Laporan Keuangan. 2(1), 410.

[3] Hardiningsih, P. (2010). PengaruhIndependensi, Corporate Governance, Dan Kualitas Audit TerhadapIntegritasLaporanKeuangan. KajianAkuntansi, 2(1), 61-76.

[4] Adhitya,T.R.(2018).PengaruhKomisarisIndependen,KomiteAudit,Kualitas Audit, Dan Leverage Terhadap Integritas Laporan Keuangan Dengan Firm Size Sebagai Variabel Moderasi Pada Perusahaan Pertambangan Yang Terdaftar Di Bursa Efek Indonesia. Tesis Universitas Sumatra Utara.

[5] Linata,Y.,Sugiarto,S.2012.PengaruhIndependensiAkuntansPublik,Kualitas Audit, Ketetapan Waktu Pelaporan serta Mekanisme Corporate Governance Terhadap Integritas Laporan Keuangan Perusahaan LQ45 yang Terdaftar di BEI periode 2007-2010. Jurn/al Akuntansi Keuangan. Vol.1 No. 1.

[6] Jama'an. 2008. Pengaruh Mekanisme Corporate Governance Dan Kualitas Kantor Akuntan Publik Terhadap Integritas Informasi Laporan Keuangan. Tesis Magister Sain Akuntansi Universitas Diponegoro,Semarang

[7] Jensen \&Meckling 1976, The Theory Of The Firm Managerial Behaviour, Agency Cost And Ownership Structure, Journal Of Financial And Economics, 3:305-360.

[8] Effendi, M. A. (2016). The Power Of Good Corporate Governance. Jagakarsa, Jakarta Selatan 12610: Salemba Empat

[9] Givoly, D. \& C. Hayn. 2000. The Changing Time-Series Properties of Earnings. Cash Flows and Accrual: Has Financial Reporting Become More Conservative? Journal of Accounting and Economics 29.287-320.

[10] Irfana, M.J. 2012. Analisis Pengaruh Debt Default, Kualitas Audit, Opinion Shoping Dan Kepemilikan Perusahaan Terhadap Penerimaan Opini Going Concern.

[11] Haruman, Tendi. (2008). "Struktur Kepemilikan, Keputusan Keuangan Dan NilaiPerusahaan".FinanceAndBankingJournal.Volume10.No.2.Hal 150165.Bandung

[12] Brigham, E,F \& Weston, J,F. 2005. Dasar-Dasar Manajemen Keuangan, Edisi Kesembilan, Jilid 2, Penerbit Erlangga, Jakarta.

[13] Astria, Tia. 2011. "Analisis Pengaruh Audit Tenure, Struktur Corporate Governance, Dan Ukuran Kap Terhadap Integritas Laporan Keuangan”.Skripsi. Program Sarjana Fakultas Ekonomi. Universitas Diponegoro.2011 
[14] Klein, A. (2002). Audit Committee, Board of Director Chararacteristics, and Earnings Management. Journal of Accounting and Economics, 33(3), 375-400.

[15] Mayangsari,Sekar,2003,AnalisisPengaruhIndependensi,KualitasAudit,Serta Mekanisme Corporate Governance Terhadap Integritas Laporan Keuangan, Simposium Nasional Akuntansi Vi, Surabaya, 16 - 17 Oktober2003

[16] Rizal, N. \&Liyundra, FS. 2016. PengaruhTekananWaktudanIndependensiterhadapKualitas Audit. JurnalPenelitianIlmuEkonomi WIGA Vol 6 No 1 Maret 2016 (45-52).

[17] Savero, D. O. (2017). Pengaruh Komisaris Independen, Komite Audit, Kepemilikan Instutisional Dan Kepemilikan Manajerial Terhadap Integritas Laporan Keuangan. Jom Fekon, 4(1), 75-89

[18] Nurjannah, L \& Pratomo, D. 2014. Pengaruh Komite Audit, Komisaris Independen dan Kualitas Audit terhadap Integritas Laporan Keuangan (Pada Perusahaan Manufaktur yang terdaftar di Bursa Efek Indonesia tahun 2012). E-Proceeding of Management: Vol.1, No.3 Desember 2014 (99). ISSN: 2355-9357

[19] Ghozali, Imam. 2018. Aplikasi Analisis Multivariate Dengan Program Ibm Spss25. Badan Penerbit Universitas Diponegoro: Semarang.

[20] Brigham, Eugene F And Ehrhardt. 2005. Dasar-Dasar Manajemen Keuangan.Edisi Kesembilan. Alih Bahasa : Jakarta : Salemba Empat.

[21] Adriansano, C. A., \& Nuryantoro. 2015. Pengaruh Independensi Auditor Dan Kualitas Audit Terhadap Kualitas Laporan Keuangan. E-Proceeding of Management: Vol.2, No.1

[22] Givoly, D. dan Hayn, C. 2002. "Rising Conservatism: Implication forFinancial Analysis.” Financial Analists Journal,56-74.

[23] Hardiningsih, P. 2010. Pengaruh Independensi, Corporate Governance, dan Kualitas Audit Terhadap Kualitas Laporan Keuangan. Kajian Akuntansi, Februari 2010 Vol 2 No. 1 Hal 61 - 76.

.[24] Hasanuddin. (2018). The Influence of Good Corporate Governance, and Quality of Audit Against the Integrity of The Financial Statemens. International Journal of Economics Management and Social Science. https://dx.doi.org/10.32484/ijemss.v1i3.17

.[25] Setiawan, B. (2015). Pengaruh Independensi, Kualitas Audit Dan Mekanisme Corporate Governance Terhadap Integritas Laporan Keuangan PerusahaanManufakturDiBursaEfekIndonesiaTahun20082012.Jom Fekon, 2(2),1-15.

[26] Sujono dan Soebiantoro, U. 2007. Pengaruh Struktur Kepemilikan Saham, Leverage, Faktor ntern dan Faktor ekstern terhadap Nilai Perusahaan. Jurnal Manajemen dan Kewirausahan. Vol. 9. No 1. Maret: 41-48. 